\title{
RELATION OF STRUCTURE TO FUNCTION IN BACTERIAL O ANTIGENS
}

\section{Isolation Methods}

\author{
ANNA M. NOWOTNY, ${ }^{1}$ SCOTT THOMAS, ${ }^{1}$ OLGA S. DURON, aNd ALOIS NOWOTNY ${ }^{1}$ \\ Department of Experimental Pathology, City of Hope Medical Center, Duarte, California
}

Received for publication 10 September 1962

\begin{abstract}
Nowotny, Anna M. (City of Hope Medical Center, Duarte, Calif.), Scotт Thomas, Olga S. Duron, AND Alois Nowotny. Relation of structure to function in bacterial $\mathrm{O}$ antigens. I. Isolation methods. J. Bacteriol. 85:418-426. 1963.-Six isolation methods, four previously described and two reported herein, were compared for the extraction of endotoxic $\mathrm{O}$ antigens from three different enterobacteria: Serratia marcescens Bizio, Salmonella typhosa 0901, and Escherichia coli K-12 lambda. Large variations were observed in the toxin yield, in the serologically reactive material yield, and in the nucleic acid-releasing abilities of the six methods when applied to the different bacterial strains. Chemical analyses of the toxic $\mathrm{O}$ antigens included quantitative determination of the amino acids, long- and short-chain carboxylic acids, and carbohydrates. Comparisons of the nucleic acid content were also made. Although the chemical composition of the preparations was quite different, no correlation could be found between the percentage of the above components and the lethal toxicity or the serological reactivity. It was concluded that the structural elements or properties responsible for these biological activities cannot be detected by gross chemical analyses.
\end{abstract}

Several $\mathrm{O}$ antigen isolation methods have been described since that first reported by Boivin and Mesrobeanu (1933). Their trichloroacetic acid extraction procedure was followed by other processes, using extraction after trypsin digestion (Raistrick and Topley, 1934), with diethyleneglycol (Morgan, 1937), formamide (Fuller, 1938), urea (Walker, 1940), different ratios of phenol

${ }^{1}$ Present address : Department of Microbiology, Temple University School of Medicine, Philadelphia, Pa. and water (Palmer and Gerlough, 1940; Westphal and Lüderitz, 1954; Goebel and Barry, 1957), pyridine-water (Goebel, Binkley, and Perlman, 1945), water only at $80 \mathrm{C}$ (Roberts, 1949), ethyl ether-water (Ribi, Milner, and Perrine, 1959), and others.

During earlier experiments in this laboratory to measure the toxicity of different $\mathrm{O}$ antigen preparations obtained from the same strain with different isolation methods, striking differences were observed. Certain extraction methods isolated an active preparation from some gramnegative strains, while the same methods, when applied to other gram-negative groups, were completely ineffective.

During recent studies concerning the molecular biology of bacterial $\mathrm{O}$ antigens, the antigenicity was of more interest than the toxicity of these preparations. It became necessary to develop new methods to produce a maximal yield of immunologically active material from a wide variety of bacterial cells. A further aim of the new extraction methods was the separation and isolation of cell constituents with different biological properties, while avoiding as far as possible the production of artifacts.

The use of surface-active agents such as detergents (Scott, 1959; Kay, Simmons, and Dounce, 1952; Cohn and Butler, 1958) seemed suitable for the nonhydrolytic dissolution or loosening of different cell structures, facilitating the release and separation of different tissue components. Application of detergent in this laboratory for the fractionation of bacterial cell components was successful. Another approach to the same goal was made with concentrated pyridinium formate, since it had been observed in earlier experiments that pyridine neutralized with acids dissolved bacterial glycolipids and glycoproteins and yielded at elevated temperatures a water-clear solution, while leaving unaffected the toxicity or serological reactivity of the preparations. 
After elaboration of these two new methods for the isolation of bacterial $\mathrm{O}$ antigens, the results obtained were compared with those from four widely used extraction procedures. All the experiments were carried out on three different gram-negative bacteria: Serratia marcescens Bizio, Salmonella typhosa O901, and Escherichia coli K-12 lambda. The isolation methods and the $\mathrm{O}$ antigen preparations were investigated (i) to carry out the quantitative chemical analysis of the preparations; (ii) to make quantitative comparisons of the $\mathrm{O}$ antigen yield of the methods; (iii) to determine quantitative toxin yield of each extraction procedure; and (iv) to study whatever relationships between chemical constituents and biological activities became apparent.

\section{Materials and Methods}

Cultivation of bacteria. From the American Type Culture Collection were obtained nonchromogenic S. marcescens Bizio (strain 264) and $E$. coli K-12 lambda (strain 10798). The $S$. typhosa 0901 was supplied by A. G. Johnson of the University of Michigan. S. marcescens bacteria were cultivated in this laboratory, and large-scale cultivation of $E$. coli and $S$. typhosa was carried out by Dr. Johnson and his coworkers.

S. marcescens Bizio (strain 264) was grown on synthetic medium: distilled water, $980 \mathrm{ml}$; $\mathrm{NaCl}, 3 \mathrm{~g} ; \mathrm{NH}_{4} \mathrm{Cl}, 2 \mathrm{~g} ; \mathrm{Na}_{2} \mathrm{HPO}_{4}$ anhydrous, $6 \mathrm{~g}$; $\mathrm{KH}_{2} \mathrm{PO}_{4}$ anhydrous, $3 \mathrm{~g}$; Casamino Acids (Difco), $1 \mathrm{~g} ; \mathrm{MgSO}_{4}(10 \%$ solution in water), $1 \mathrm{ml}$. After this mixture was sterilized in the autoclave, 20 $\mathrm{ml}$ of $25 \%$ sterile dextrose were added. The final dextrose concentration was $0.5 \%$. After $18 \mathrm{hr}$ of incubation on this medium, the cells were harvested by centrifugation, washed once with water, and killed with acetone.

For the cultivation of $S$. typhosa 0901 and $E$. coli K-12 lambda strains, the following medium was used: distilled water, $1,000 \mathrm{ml} ; \mathrm{K}_{2} \mathrm{HPO}_{4}$, $11.65 \mathrm{~g} ; \mathrm{KH}_{2} \mathrm{PO}_{4}, 1.90 \mathrm{~g} ; \mathrm{MgSO}_{4}, 0.50 \mathrm{~g}$; thiamine $\mathrm{HCl}, 0.30 \mathrm{~g}$; niacin, $0.01 \mathrm{~g}$; L-asparagine, $2.50 \mathrm{~g}$; peptone, $0.03 \mathrm{~g}$; glucose, $10.00 \mathrm{~g}$. Further treatments were the same as above.

1. I solation methods. The trichloroacetic acid extraction method (TCA) used was basically identical with that originally described by Boivin, Mesrobeanu, and Mesrobeanu (1933). Dried cells $(10 \mathrm{~g})$ were mixed with $1,000 \mathrm{ml}$ of water under gentle stirring for $60 \mathrm{~min}$. Washing fluid was separated by centrifugation at $6,000 \times g$ for $30 \mathrm{~min}$, and the supernatant was discarded. To the wet sediment, $300 \mathrm{ml}$ of $5 \%$ trichloroacetic acid were added and homogenized in a Servall Omnimixer at top speed under ice-water cooling for $2 \mathrm{~min}$, followed with medium-speed stirring for $8 \mathrm{~min}$. Centrifugation at $6,000 \times g$ for 30 min separated the $\mathrm{O}$ antigens in the supernatant from the sedimented cells and cell debris. The sediment was extracted two more times with $200 \mathrm{ml}$ of $5 \%$ trichloroacetic acid in each extraction. The pooled supernatant was dialyzed, filtered, and freeze-dried.

This crude extract could be purified when extracted with anhydrous methanol. To $1 \mathrm{~g}$ of dry $\mathrm{O}$ antigen, $250 \mathrm{ml}$ of methanol were added, and the suspension was refluxed on a hot-water bath under constant magnet-stirring for $60 \mathrm{~min}$, then filtered through an $\mathrm{M}$ glass filter and dried in a vacuum desiccator. This procedure removed nonbound lipids from the crude extract, but did not influence the toxicity, pyrogenicity, nonspecific resistance-increasing effect, or the serological properties of the preparations.

2. The application of phenol for the isolation of bacterial antigens (Palmer and Gerlough, 1940) became popular after Westphal and Lüderitz (1954) reported a modification. The procedure (PHW) was applied as follows. To $10 \mathrm{~g}$ of dry cells, $1,000 \mathrm{ml}$ of distilled water were added. The mixture was stirred slowly for $60 \mathrm{~min}$ at room temperature, centrifuged, and the supernatant discarded. The wet washed-cell sediment was mixed with water and filled up to a total volume of $300 \mathrm{ml}$. To this suspension, $300 \mathrm{ml}$ of phenolwater $(9: 1)$ were added. The mixture was heated up to $70 \mathrm{C}$ in a warm-water bath under constant stirring, kept at this temperature for $10 \mathrm{~min}$, cooled, and centrifuged at $1,500 \times g$ for 60 min. The supernatant, containing the watersoluble lipopolysaccharides, nucleic acids, and some other constituents, was decanted by suction. The remaining interphase, phenol, and nonsoluble cell residue were extracted two more times with $250 \mathrm{ml}$ of water added at each step at $70 \mathrm{C}$ for $10 \mathrm{~min}$, as above. The pooled watersoluble extracts were dialyzed for $72 \mathrm{hr}$ against distilled water in a cold room, filtered, and concentrated by vacuum distillation to approximately $50 \mathrm{ml}$. To this thick solution, $500 \mathrm{ml}$ of methanol were added, and let stand in a cold 
room overnight. The formation of precipitate could be accelerated by adding $10 \mathrm{ml}$ of ethanol saturated with $\mathrm{Na}$ acetate to the extract. The precipitated lipopolysaccharides containing the $\mathrm{O}$ antigens were sedimented by $1,500 \times g$ centrifugation and washed once with $100 \mathrm{ml}$ of cold $\mathrm{MeOH}$. The sediment, after being dissolved in $200 \mathrm{ml}$ of water, had to be vacuum distilled to remove the methanol. The alcohol-free, milky solution could be dried from the frozen state. No further purification was done.

3. The most simple and effective method (W) for the isolation of a potent $\mathrm{O}$ antigen was described by Roberts (1949). After being washed with cold water as described above, $10 \mathrm{~g}$ of dry cells were suspended in $1,000 \mathrm{ml}$ of water, warmed to $80 \mathrm{C}$ under constant stirring, and kept at this temperature for $30 \mathrm{~min}$. The material was cooled to room temperature, then centrifuged at $6,000 \times g$ for $30 \mathrm{~min}$. The residue was extracted twice more with $500 \mathrm{ml}$ of water at $80 \mathrm{C}$. The pooled supernatant was dialyzed, filtered, concentrated in vacuum, and lyophilized. For this investigation, no further purification was applied.

4. The use of water saturated with ethyl ether (AQE) for endotoxin isolation was introduced by Ribi and co-workers (1959). In this laboratory, their procedure was slightly modified as follows. Dry cells (10 g) were washed as before and, to the wet sediment, $600 \mathrm{ml}$ of water were added. The mixture was then homogenized. After addition of $100 \mathrm{ml}$ of ethyl ether, the mixture was vigorously shaken for $1 \mathrm{~min}$. The suspension was separated by cold centrifugation at $6,000 \times g$ for $30 \mathrm{~min}$ in plastic tubes closed with rubber caps. The water and ether phases were collected by decanting the fluid from the sediment. The extraction was repeated twice more, with 300 $\mathrm{ml}$ of water and $50 \mathrm{ml}$ of ether added to the residue at each step. The water phase had to be separated from the ether, dialyzed, filtered, concentrated in vacuum to approximately 100 $\mathrm{ml}$, and freeze-dried. No further purification was carried out in these experiments.

5. Different pyridinium compounds were tried for the extraction of glycolipids from bacterial cells, and the best results were obtained using an equimolar mixture of anhydrous pyridine and concentrated formic acid (PYF). To the wet sediment of $10 \mathrm{~g}$ of water-washed bacteria obtained by the previously described method, $100 \mathrm{ml}$ of pyridine-formic acid $(76: 49)$ were added, warmed in a boiling-water bath under constant stirring for $30 \mathrm{~min}$, cooled, then centrifuged at $6,000 \times g$ for $30 \mathrm{~min}$. To the residue, $50 \mathrm{ml}$ of the above mixture were added, and the extraction was repeated twice more. The pooled supernatants were diluted with 20 volumes of water, dialyzed, filtered, concentrated in vacuum to approximately $200 \mathrm{ml}$, and precipitated with 10 volumes of cold methanol. The precipitate after centrifugation had to be washed twice with cold methanol. The sediment could be dissolved in water and, after removal of the methanol by vacuum distillation, freeze-dried.

6, Cetyltrimethylammonium bromide (CTB) in $0.5 \%$ solution was used to liberate $\mathrm{O}$ antigens from the bacterial cell walls. To the centrifuged and water-washed sediment of $10 \mathrm{~g}$ of dry cells were added $300 \mathrm{ml}$ of $0.5 \%$ CTB. The mixture was homogenized at $5 \mathrm{C}$ in a Servall mixer, at top speed for 2 min and at medium speed for 8 min. The very foamy suspension separated when centrifuged at $8,000 \times g$ for 30 min at $5 \mathrm{C}$. The sediment was extracted twice more with a total of $600 \mathrm{ml}$ of CTB. The pooled supernatant was precipitated with 4 volumes of cold $\mathrm{MeOH}$, and centrifuged at $1,500 \times g$ for $30 \mathrm{~min}$. The supernatant was discarded, and the sediment was washed twice with $100 \mathrm{ml}$ of $80 \% \mathrm{MeOH}$, with vigorous agitation of the sediment. The precipitate was soluble in water, and, after removal of $\mathrm{MeOH}$ remnants, could be lyophilized.

Biological and immunochemical tests. Mouse lethal toxicity was determined with Swiss albino mice (18 to $20 \mathrm{~g}$ ), which were injected intraperitoneally with the preparations dissolved in saline containing Merthiolate in a dilution of $1: 10,000$. Calculation of the $\mathrm{LD}_{50}$ was made according to Irwin and Cheeseman (1939). The yield of toxic material was calculated as the number of $\mathrm{LD}_{50}$ isolated from $1 \mathrm{~g}$ of dried bacterial cells. Results are summarized in Table 1.

The serological reactivity of the $\mathrm{O}$ antigen obtained by the methods described herein was first investigated by a semiquantitative microdiffusion method. Microscopic slides were covered with $2 \mathrm{ml}$ of a $0.5 \%$ solution of ionagar (Consolidated Laboratories, Inc., Chicago Heights, Ill.) containing $0.01 \%$ Merthiolate. The pattern shown on Fig. 1 was cut into the agar with a technique similar to that used for immunoelectrophoresis. Distance between wells and channel was always $3 \mathrm{~mm}$. The diameter of the wells 
TABLE 1. Yield of the procedures and biological properties of the preparations*

\begin{tabular}{|c|c|c|c|c|c|c|c|c|}
\hline Strain & $\begin{array}{c}\text { No. of } \\
\text { prepn }\end{array}$ & $\begin{array}{l}\text { Isolation } \\
\text { method }\end{array}$ & $\begin{array}{l}\text { Per cent } \\
\text { material } \\
\text { yield of the } \\
\text { method }\end{array}$ & $\begin{array}{l}\text { Mice lethal } \\
\text { toxicity } \\
\text { (LD } 50 \text { in } \mu \mathrm{g} \text { ) }\end{array}$ & $\begin{array}{l}\text { Toxic ma- } \\
\text { terial yield } \\
\text { of the meth- } \\
\text { od ( } \mathrm{LD}_{60} \\
\text { from } 1 \mathrm{~g} \\
\text { of cells) }\end{array}$ & $\begin{array}{l}\text { Maximal } \\
\text { dilution } \\
\text { giving } \\
\text { precipitate }\end{array}$ & $\begin{array}{c}\text { Ratio of } \\
\text { precipitated } \\
\text { N/antigen } \\
(\mu \mathrm{g} / \mu \mathrm{g})\end{array}$ & $\begin{array}{c}\text { O antigen } \\
\text { yield of } \\
\text { the meth- } \\
\text { od }\end{array}$ \\
\hline Serratia marcescens & 1 & TCA & 15 & 150 & 1,000 & $1: 64$ & 5.1 & 76 \\
\hline \multirow[t]{5}{*}{ Bizio } & 2 & PHW & 5 & 1,600 & 31 & $1: 32$ & 4.5 & 22 \\
\hline & 3 & W & 29 & 450 & 640 & $1: 32$ & 2.9 & 84 \\
\hline & 4 & AQE & 27 & 760 & 350 & $1: 64$ & 1.2 & 32 \\
\hline & 5 & PYF & 38 & 610 & 620 & $1: 32$ & 2.3 & 87 \\
\hline & 6 & CTB & 28 & 370 & 760 & $1: 2$ & 0.04 & 1 \\
\hline Salmonella typhosa & 7 & TCA & 5 & 360 & 140 & $1: 8$ & 1.9 & 9 \\
\hline \multirow[t]{5}{*}{ O901 } & 8 & PHW & 6 & 160 & 310 & $1: 16$ & 2.6 & 16 \\
\hline & 9 & $\mathbf{W}$ & 13 & 4,020 & 31 & $1: 8$ & 1.4 & 18 \\
\hline & 10 & AQE & 52 & 1,520 & 340 & $1: 4$ & 0.9 & 47 \\
\hline & 11 & PYF & 36 & 1,070 & 340 & $1: 4$ & 0.8 & 29 \\
\hline & 12 & CTB & 40 & 810 & 500 & $1: 2$ & 0.5 & 20 \\
\hline \multirow[t]{6}{*}{ Escherichia coli K-12 } & 13 & TCA & 3 & 5,200 & 6 & $1: 1$ & 0.2 & 1 \\
\hline & 14 & PHW & 3 & 420 & 71 & $1: 2$ & 1.0 & 3 \\
\hline & 15 & W & 21 & 1,900 & 110 & $1: 1$ & 0.1 & 2 \\
\hline & 16 & AQE & 30 & 2,600 & 110 & $1: 2$ & 0.6 & 18 \\
\hline & 17 & PYF & 13 & 4,400 & 30 & $1: 1$ & 0.4 & 5 \\
\hline & 18 & CTB & 14 & 380 & 370 & $1: 8$ & 2.0 & 28 \\
\hline
\end{tabular}

* Explanations are given in Materials and Methods.

was $2 \mathrm{~mm}$, as was the width of the channel in the middle of the slide. The wells were filled with $1: 1,1: 2,1: 4$, etc., of $\mathrm{O}$ antigen dilutions, starting with a $1-\mathrm{mg} / \mathrm{ml}$ standard solution in physiological $\mathrm{NaCl}$. The channel was filled with rabbit $\mathrm{O}$ antiserum obtained by using a heat-killed suspension of bacteria as antigen mixed with Freund's adjuvant. The plates were incubated in a water-saturated atmosphere at $37 \mathrm{C}$ for 18 to $24 \mathrm{hr}$, transferred to a cold room, and read after 5 days. The highest dilution which still gave a visible precipitation zone was registered. (Results of this micro method are shown in Table 1.)

The quantitative ultramicroprecipitin test, the so-called bromsulphalein method of Glick et al. (1958), was used to determine the serological reactivity of the preparations with homologous rabbit $\mathrm{O}$ antiserum. To a standard amount of serum, different dilutions of antigen were added. The maximum of the precipitation curves was considered as the optimal antigen-antibody ratio without respect to the fact that the antigen preparations used were mixtures of several antigens. From the maximum of the precipitation curves, the amount of precipitated $\mathrm{N}$ was calculated. The data do not include corrections, which would be necessary because of the $\mathrm{N}$ content of the antigens. Table 1 gives the precipitated $\mathrm{N}$ per antigen ratios. These data give information about the serological reactivity of the isolated materials. The $\mathrm{O}$ antigen yield of the different methods (Table 1) was obtained when the serological reactivity was multiplied by the percentage yield of the methods. These data represent the weight units (for example, micrograms) of $\mathrm{N}$ which could be precipitated by the total extracted material obtained from 100 weight units of bacteria. Comparison of these numbers shows the relative effectiveness of the procedures.

Chemical analysis. Short- and long-chain fatty acid content was determined with the $\mathrm{BF}_{3}$ method (Duron and Nowotny, Anal. Chem., in press). Ninhydrin-positive components were investigated after $8 \mathrm{hr}$ of hydrolysis with $5 \mathrm{~N} \mathrm{HCl}$ in sealed tubes in a boiling-water bath. The hydrolysates were dried in a vacuum desiccator over potassium hydroxidepellets, and the neutral residues taken up in water, with $0.2 \mathrm{ml}$ added for each $\mathrm{mg}$ of original $\mathrm{O}$-antigen preparation. The dissolved residue was investigated by high-voltage paper electrophoresis; the results are shown in Fig. 2. The ninhydrin-sprayed strips were developed, then "fixed" with $\mathrm{CuNO}_{3}$-acetone solution, 


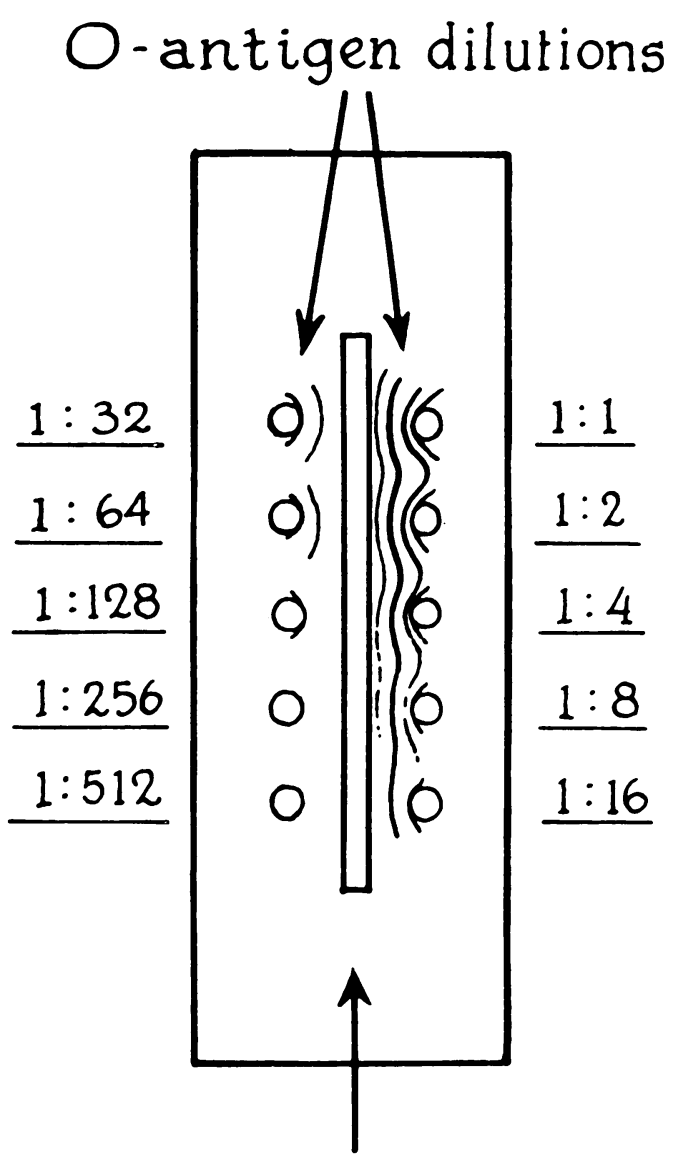

\section{O- antiserum}

FIG. 1. Microdiffusion plate. Trichloroacetic acid-extracted $O$ antigen from Serratia marcescens in the wells. Homologous rabbit $O$ antiserum in the central channel.

prepared according to Bode (1955). Quantitative amino acid determinations in the above hydrolysate were carried out by the method of Moore and Stein (1954), and for the measurement of the hexosamine content the procedure of Rondle and Morgan (1955) was used. Carbohydrate determinations were made by the anthrone method of Koehler (1952), and by the Somogy (1945) procedure. For the latter method, hydrolysis of the samples was done using $1 \mathrm{~N}$ sulfuric acid on a boiling-water bath for $20 \mathrm{hr}$. The samples were neutralized and filled up to a known volume.

\section{Results}

All the methods investigated resulted in water-soluble preparations. The yield of the procedures, shown in Table 1, varies from 3 to $52 \%$, depending on the method used and the bacterial strain.

Some of the preparations (for example, the $\mathrm{O}$ antigens extracted with aqueous ether or warm water) were not, of course, homogenous materials, as could be seen from the results of chemical analysis. Many of the 18 different antigen preparations contained components of the protoplasm, which could be removed by further fractionation. Preparative ultracentrifugation sedimented the $\mathrm{O}$ antigen complexes, leaving the bulk of ultraviolet-absorbing components in the supernatant. Using the purification procedure for $\mathrm{O}$ antigen extracted with aqueous ether described by Ribi and co-workers (1959), inert proteins and nonbound lipids could be removed. Detergentextracted preparations with a high protein content could also be separated into toxic and nontoxic protein fractions with a cold ethanol fractionation procedure. This way of isolating $\mathrm{O}$ antigen and other cell components is under further study.

In this work, we were interested in the amount of total extractable toxic and antigenic components which could be obtained in water-soluble form by means of the different procedures. Therefore, we decided against prolonged fractionation and purification, to avoid any eventual loss of toxic or antigenic materials during further treatments.

The biological properties of the preparations and the yield of the procedures are also summarized in Table 1. Examination of the results showed that the pyridinium formate method gave good average yield in toxic and serologically active materials when used for the extraction of $S$. marcescens or $S$. typhosa materials. Detergent extraction produced high amino acid content and almost the best toxin yield in all three strains. The yield of extractable antigens was practically zero when this method was applied to $S$. marcescens but good when used with $S$. typhosa, and best of all with $E$. coli K-12 lambda. A good yield could be obtained by the aqueous ether procedure as well; however, it was not the best in all strains. The phenol-water method produced very active endotoxin when used with E. coli 055, O8, or 0111 strains (Westphal and Lüderitz, 1954). The same procedure applied to $E$. coli K-12 lambda in this laboratory gave a relatively poor yield. The phenol-water extraction method was practically useless for $S$. marcescens, 


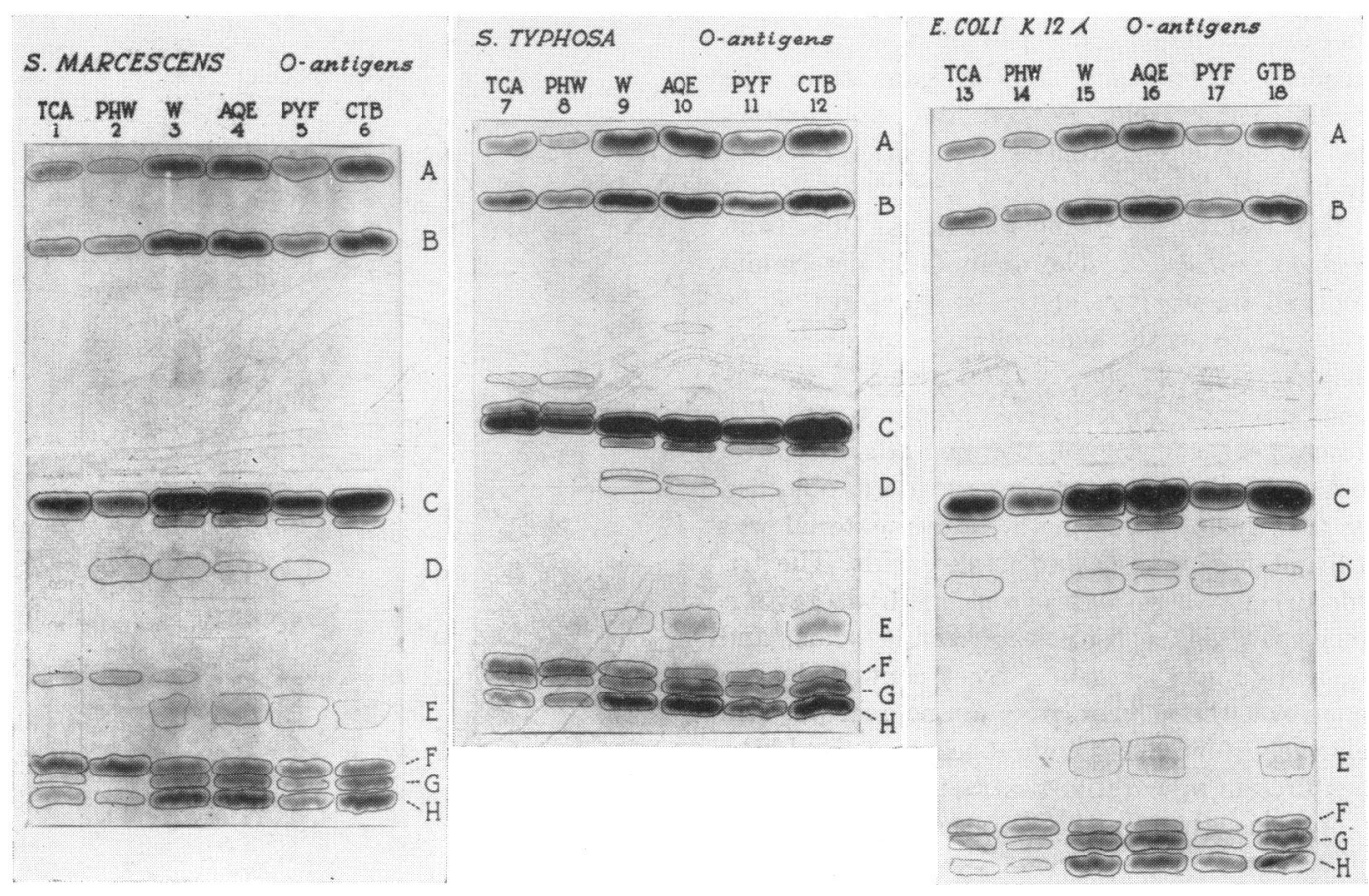

FIG. 2. High-voltage paper electrophoresis of the hydrolysates of the antigens developed with ninhydrin. A, aspartic acid; B, glutamic acid; C, neutral amino acids; D, nucleotide bases; E, basic peptides; F, glucosamine; $\mathrm{G}$, arginine; $\mathrm{H}$, lysine.

TABLE 2. Chemical analysis of the $O$ antigen preparations*

\begin{tabular}{|c|c|c|c|c|c|c|c|c|}
\hline Strain & $\begin{array}{c}\text { No. of } \\
\text { prepn }\end{array}$ & $\begin{array}{c}\text { Isolation } \\
\text { method }\end{array}$ & $\begin{array}{l}\text { Long-chain } \\
\text { fatty acids }\end{array}$ & $\begin{array}{c}\text { Volatile } \\
\text { fatty acids }\end{array}$ & $\begin{array}{c}\text { Amino } \\
\text { acids }\end{array}$ & $\begin{array}{l}\text { Anthrone- } \\
\text { positive car- } \\
\text { bohydrates }\end{array}$ & $\begin{array}{l}\text { Total re- } \\
\text { ducing car- } \\
\text { bohydrates }\end{array}$ & $\begin{array}{c}\text { Hexo- } \\
\text { samines }\end{array}$ \\
\hline & & & $\%$ & $\%$ & $\%$ & $\%$ & $\%$ & $\%$ \\
\hline Serratia marcescens & 1 & TCA & 15.6 & 3.7 & 8.3 & 34.2 & 36.0 & 4.0 \\
\hline \multirow[t]{5}{*}{ Bizio } & 2 & PHW & 8.6 & 2.8 & 7.3 & 21.8 & 20.6 & 4.4 \\
\hline & 3 & W & 9.2 & 1.5 & 25.8 & 17.5 & 24.9 & 1.9 \\
\hline & 4 & AQE & 8.6 & 0.6 & 38.7 & 14.9 & 17.5 & 2.8 \\
\hline & 5 & PYF & 14.6 & 1.5 & 19.5 & 19.1 & 18.9 & 2.0 \\
\hline & 6 & CTB & 10.2 & 0.8 & 38.8 & 17.2 & 26.6 & 3.1 \\
\hline Salmonella typhosa & 7 & TCA & 19.4 & 0.6 & 21.1 & 13.3 & 18.4 & 7.3 \\
\hline \multirow[t]{5}{*}{0901} & 8 & PHW & 9.6 & 1.1 & 17.2 & 25.0 & 25.4 & 5.3 \\
\hline & 9 & W & 7.6 & 0.3 & 43.6 & 6.4 & 11.2 & 2.7 \\
\hline & 10 & $\mathrm{AQE}$ & 12.0 & 0.1 & 69.5 & 3.8 & 5.9 & 1.7 \\
\hline & 11 & PYF & 15.1 & 0.3 & 25.1 & 6.5 & 12.3 & 1.5 \\
\hline & 12 & CTB & 7.1 & 0.2 & 71.2 & 4.3 & 6.3 & 1.8 \\
\hline \multirow[t]{6}{*}{ Escherichia coli $\mathrm{K}-12$} & 13 & TCA & 3.9 & 0.0 & 17.0 & 11.8 & 9.3 & 1.4 \\
\hline & 14 & PHW & 7.5 & 0.0 & 9.7 & 19.7 & 12.9 & 2.0 \\
\hline & 15 & W & 6.0 & 0.1 & 43.3 & 4.8 & 5.2 & 1.2 \\
\hline & 16 & $\mathrm{AQE}$ & 7.3 & 0.1 & 53.8 & 3.0 & 6.5 & 1.0 \\
\hline & 17 & PYF & 2.2 & 0.0 & 18.9 & 6.4 & 6.5 & 0.7 \\
\hline & 18 & CTB & 15.2 & 0.0 & 48.3 & 6.7 & 11.1 & 2.2 \\
\hline
\end{tabular}

\footnotetext{
* Explanations are given in Materials and Methods.
} 
but the trichloroacetic acid method gave an excellent preparation. At the same time, the trichloroacetic acid method did not extract the endotoxic $\mathrm{O}$ antigens from $E$. coli $\mathrm{K}-12$ lambda.

The results of chemical analysis are summarized in Table 2. The amino acid determination and the analysis of the hydrolysates of the preparations with high-voltage paper electrophoresis (Fig. 2) showed that none of the six methods gave peptide-free preparations. The amino acid content of the $\mathrm{O}$ antigens varies widely. While the lowest percentage was obtained by the phenol-water method, the material was still not free from bound amino acids. The trichloroacetic acid extraction method gave a somewhat higher content of amino acids, and the pyridinium formate extract contained even more; yet, the percentage of amino acid was still relatively low. The highest content could be measured in preparations extracted by detergent, in aqueous ether, or in hot water.

The fatty acid content of the $\mathrm{O}$ antigens also varies, but more striking differences could be seen in their carbohydrate content. Some gave surprisingly low values, such as the quite active $\mathrm{O}$ antigen extracted by aqueous ether from $S$. typhosa or $E$. coli K-12. The anthrone values were reached after $10 \mathrm{~min}$ of heating in a water bath. According to Koehler (1952), the aldopentoses and some other carbohydrates are destroyed after a few minutes of heating with the anthrone agent, and the remaining color intensity is due to the presence of aldohexoses. The differences between the carbohydrate values obtained by measuring the reducing and the anthronepositive carbohydrate contents can be due to the presence of aldopentoses. In those few cases where the anthrone-positive carbohydrate was higher than the total reducing carbohydrate content, we have to assume the presence of anthrone-positive but not reducing compounds.

The nucleic acid content of the preparations was compared by recording the ultravioletabsorption curves of $0.01 \%$ solutions prepared from the $\mathrm{O}$ antigens. The curves are shown in Fig. 3. Some information could be obtained also from the high-voltage paper electrophoresis analysis of the hydrolysates. Nucleotide bases, shown on Fig. 2, gave pale yellow spots on the ninhydrin-sprayed paper sheets developed in the dark at room temperature. They migrated towards the negative end of the paper.
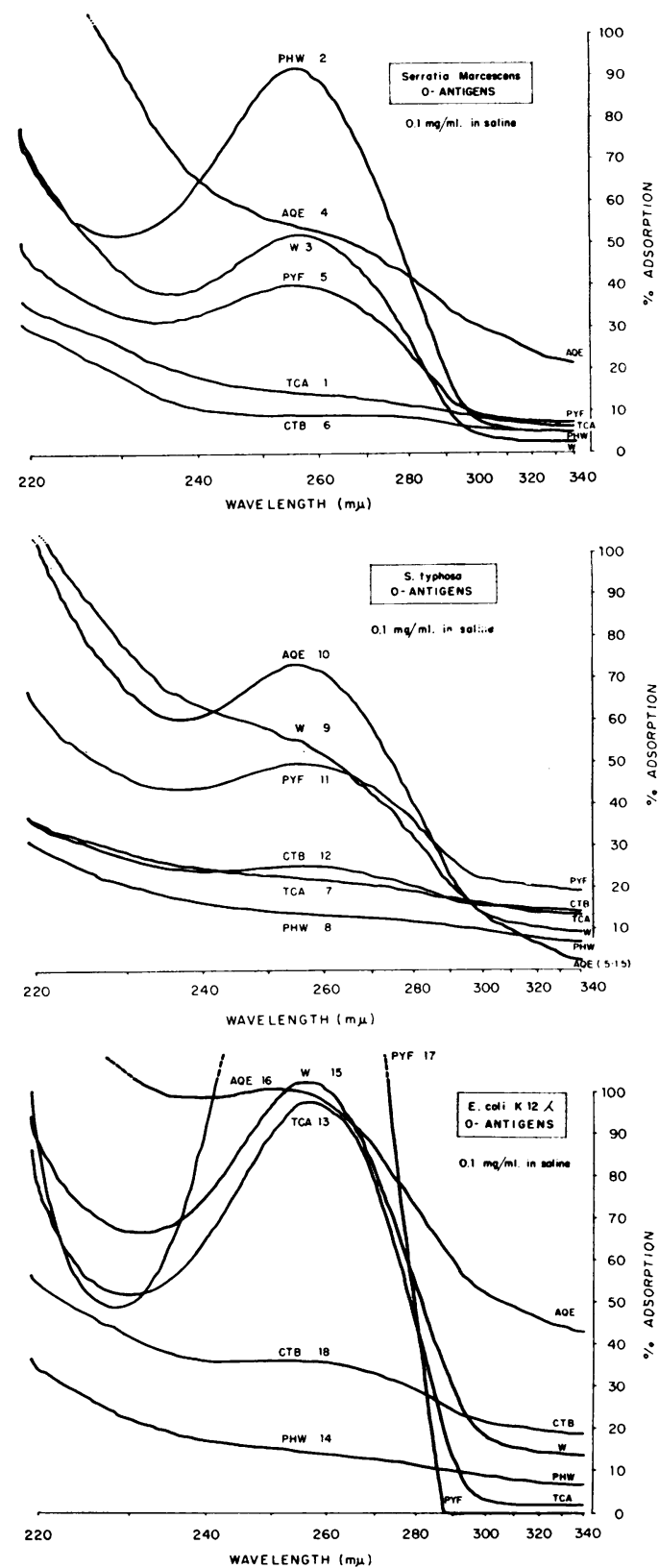

FIG. 3. Ultraviolet-absorption curves of the antigen solutions.

Great differences could be seen in the ultraviolet-absorbing component of the preparations. For example, trichloroacetic acid extracted practically no nucleic acids from $S$. marcescens but a very large amount from $E$. coli. The phenol-water method produced a preparation 
with a high content of nucleic acid from $S$. marcescens but extracted none from $E$. coli K-12. Pyridinium formate extracted such a large amount of ultraviolet-absorbing material from $E$. coli K-12 that it could not be recorded at all using concentrations identical with other $\mathrm{O}$ antigens. The same method when applied to $S$. marcescens or $S$. typhosa yielded other preparations with relatively low ultraviolet-absorption.

\section{Discussion}

The first conclusion is that no one of the methods described can be applied generally for all gram-negative $\mathrm{O}$ antigen isolations. The different tribes of Enterobacteriaceae, as investigated here, each required a different isolation procedure. This fact shows that the binding forces which keep the $\mathrm{O}$ antigen complexes built into the cell wall are strikingly different. Comparison of the toxic material yield with the yield of the serologically reactive material shows, in some cases, a certain parallelism. The fit of these data depends on the ability of the extraction method to dissolve the cell wall. Some of the isolation methods produced highly toxic preparations with relatively low antigenicity; others showed high serological reactivity with moderate toxicity. The extraction method using cationic detergents yielded a highly toxic material, which reacted hardly at all with homologous $\mathrm{O}$ antiserum. Control experiments showed that the preparation contained no remnants of detergents.

Consideration of the fact that the quantitative yield of toxic material and the quantitative $\mathrm{O}$ antigen yield did not run parallel in all investigated cases suggested that the toxicity of $\mathrm{O}$ antigen preparations is not related to its antigenicity.

The chemical composition of the $\mathrm{O}$ antigen preparations was also quite different. The percentage of their content of amino acids, fatty acids, carbohydrates, and nucleic acids showed wide variation. Not only did the total amounts of these components differ but their composition as well, as could be seen by analysis of the carbohydrate. This fact becomes obvious when one supposes that the different extraction methods split different cohesive forces in the cell wall during the liberation of the endotoxic $\mathrm{O}$ antigen complexes. These experiments showed that different isolation methods dissolved different parts or layers of the cell structure. Study of these methods could therefore result in procedures which will isolate preparations important not only in investigations of the structural units of the cell wall, but in clarification of their biological significance.

Evaluation of these experiments led to the conclusion that the measured amino acid or the anthrone-positive carbohydrate content could not be related to the biological reactions under study, including the serological reaction. Although all the preparations contained considerable amounts of long-chain fatty acids, their amounts showed no obvious parallelism to the biological properties. If they are involved in some endotoxic reaction, only a part of the total may participate in these phenomena.

There are remarkable differences in the nucleic acid content of the different preparations, which were investigated by recording the ultraviolet absorption of samples containing $0.1 \mathrm{mg} / \mathrm{ml}$. Some of the extraction methods released a very large amount of nucleic acid or nucleoprotein, but did not produce a similar preparation when used for another strain.

The release of these ultraviolet-absorbing materials is not related to the yield of toxic or antigenic material from the cell wall. Most probably, the size and nature of the damage caused in the bacterial cell wall and protoplasm membrane by the different methods could be related to the release of materials absorbing in the $260-\mathrm{m} \mu$ region. The results indicate that great differences exist in the resistance of different enterobacterial membranes against chemical treatments.

Another conclusion which could be drawn from these observations is that the biologically active centers in these endotoxic $O$ antigen preparations cannot be detected and chemically identified using gross analyses like total amino acid, fatty acid, or carbohydrate determinations. The active centers in these highly complex structures are only very small fragments of the whole large molecule, or the biological activities require a highly specific steric arrangement of the structure in which the individual building blocks play only secondary roles.

The differences reported here prohibit comparison with experimental results obtained by different investigators when the experiments were not carried out using the same strain. It is possible that some of the discrepancies between the opinions of different scientific groups are 
due largely to the individual properties of the bacterial strains studied.

\section{AcKNowledgments}

This work was supported in part by grant E-3849 from the National Institute of Allergy and Infectious Diseases, U.S. Public Health Service, and grant G-18109 from the National Science Foundation.

The authors are greatly indebted to A. G. Johnson (University of Michigan) for the largescale cultivation of bacteria.

\section{LITERATURE CITED}

Bode, F. 1955. Eine Vereinfachung und Verbesserung der Methode zur qualitativen Bestimmung von Aminosäuren und Peptiden mittels des Ninhydrin-Kupferkomplexes. Biochem. Z. 326:433-435.

Boivin, A., J. Mesrobeanu, and L. Mesrobeanu. 1933. Technique pour la préparation des polysaccharides microbiens spécifiques. Compt. Rend. Soc. Biol. 113:490-492.

Cohn, P., ANd J. A. V. Butler. 1958. Fractionation of proteins of the microsomes of rat liver by means of a non-ionic detergent. Biochem. J. 70:254-260.

Fuller, A. T. 1938. The formamide method for the extraction of polysaccharides from haemolytic Streptococci. Brit. J. Exptl. Pathol. 19:130-139.

Glick, D., R. A. Good, L. J. Greenberg, J. J. EDDY, AND N. K. DAY. 1958. Measurement of precipitin reactions in the millimicron protein-nitrogen range. Science 128:1625-1626.

Goebel, W. F., and G. T. Barry. 1957. Colicine K. II. The preparation and properties of a substance having colicine $\mathrm{K}$ activity. $\mathrm{J}$. Exptl. Med. 107:185-209.

Goebel, W. F., F. Binkley, and E. Perlman. 1945. Studies on the Flexner group of dysentery bacilli. I. The specific antigens of Shigella paradysenteriae. J. Exptl. Med. 81:315330.

Irwin, J. O., And E. A. Cheeseman. 1939. On an approximate method of determining the median effective dose and its error, in the case of quantal response. Am. J. Hyg. 39:574-580.

Kay, E. R. M., N. S. Simmons, and A. L. Dounce. 1952. An improved preparation of $\mathrm{Na}$ desoxyribonucleate. J. Am. Chem. Soc. 74:1724-1726.

Koehler, L. H. 1952. Differentiation of carbohydrates by anthrone reaction rate and color intensity. Anal. Chem. 24:1576-1579.

Moore S., ANd W. H. Stein. 1954. A modified ninhydrin reagent for the photometric determination of amino acids and related compounds. J. Biol. Chem. 211:907-913.

Morgan, W. T. J. 1937. Studies in immunochemistry. II. The isolation and properties of a specific antigenic substance from $B$. dysenteriae. Biochem. J. 31:2003-2021.

Palmer, J. W., and T. D. Gerlough. 1940. A simple method for preparing antigenic substances from the typhoid bacillus. Science $92: 155-156$.

Raistrick, H., and W. W. C. Topley. 1934. Immunizing fractions isolated from Bact. aertrycke. Brit. J. Exptl. Pathol. 15:113-130.

Ribi, E., K. C. Milner, and T. D. Perrine. 1959. Endotoxic and antigenic fractions from the cell wall of Salmonella enteritidis. J. Immunol. 82:75-84.

RoBerts, R. S. 1949. The endotoxin of Bact. coli. J. Comp. Pathol. Therap. 59:284-304.

Rondle, C. J. M., and W. T. J. Morgan. 1955. The determination of glucosamine and galactosamine. Biochem. J. 61:586-589.

Scotт, J. E. 1959. Aliphatic ammonium salts in the assay of acidic polysaccharides from tissue. Methods Biochem. Anal. 8:145-197.

Somogy, M. 1945. A new reagent for the determination of sugars. J. Biol. Chem. 160:61.

WALKER, J. 1940. A method for the isolation of toxic and immunizing fractions from bacteria of the Salmonella group. Biochem. J. 34:325329 .

Westphal, O., and O. Lüderitz. 1954. Chemische Erforschung von Lipopolysacchariden gramnegativer Bakterien. Angew. Chem. 66:407417. 